\title{
From Primate Communication to Human Language: Anthropological \& Philosophical Speculations
}

\author{
Ryan J. Trubits \\ Department of Anthropology, University of North Texas, Denton, Texas 76203 USA \\ Canisius College, Anthropology Division, Buffalo, New York 14208-1098 USA
}

Received $21^{\text {th }}$ October 2014; accepted $26^{\text {th }}$ February 2015

\section{OD KOMUNIKACE PRIMÁTU゚ K LIDSKÉ ŘEČI: ANTROPOLOGICKÉ A FILOZOFICKÉ SPEKULACE}

ABSTRAKT Mluvená řeč nezanechává v lidské evoluci žádné přímé empiricky vysledovatelné stopy. Původ a raná historie lidské komunikace stále čekají na vědecký výklad. Řeč slouží jako nástroj myšlení, který není omezen časem a prostorem. Je to unikátní systém podporující nekonečnou lidskou kreativitu. Pro správnou analýzu jazyka musí vědci nalézt vztahy společné všem formám komunikace. Při přípravě tohoto př́spěvku byly proto využity poznatky získané ze studia komunikačních systémů primátů, zejména lidoopů. Posun od systémů zviřecí komunikace k lidským symbolickým jazykům byl zapříčiněn celou řadou faktorů. Raní hominidé užívali a rozvíjeli stále komplexnější jazyk jako nástroj v rámci své adaptační a reprodukční strategie.

KLÍČOVÁ SLOVA Komunikace; evoluce; řeč; tvorba nik; optimální strategie při získávání potravy; primáti; prajazyk

ABSTRACT Spoken language has left no direct empirical traces in human evolution; the origin and early history of communication in humans has been left open for interpretation. Language provides a means for reflection that is limitless in space and time, and it is a unique system that promotes endless creativity. In order for a proper analysis of language, researchers must find universals shared by all forms of communication. Through the insights gained in decoding primate communication systems, this article covers those studies that have tested the potentialities of comprehension in the great apes. A set of events caused a shift from animal communication systems to human symbolic languages. In this anthropological and evolutionary context, early hominids utilized and developed ever-more complex language for adaptation and reproduction.

KEY WORDS Communication; evolution; language; niche construction; optimal foraging; primates; proto-language

\section{OPENING REMARKS}

Animal Communication Systems (ACS), in early hominids, gradually emerged into a proto-language due to the necessity for the usage of displacement, which resulted in a specific niche that permitted the successful survival and reproduction of early hominids; this process led to the symbolic language of today. Language is distinctly human, "it is the foundation on which all modern human behavior rest(s)" (Johanson et al. 2006, 106). Language affects all aspects of how humans perceive the world, but at this time scientists are unaware of its origin. Having an evolutionary framework of language is vital to concretely knowing the unique nature of what it means to be human. In addition, it is vital to coming to terms with the necessity for the growth of societies, the flourishing of technology, and the "inextricably entwined...symbolic consciousness" (Tattersall 2010, 4) that we experience today.

Researchers debate on interpreting the evolutionary development of human language as a gradual process, or as one that is a punctuated adaptation. Anatomically and neurologically speaking, language in non-human primates is physically impossible to achieve; they are unable to produce the sounds necessary to emulate language. This genetic breakthrough is only present in modern humans. 


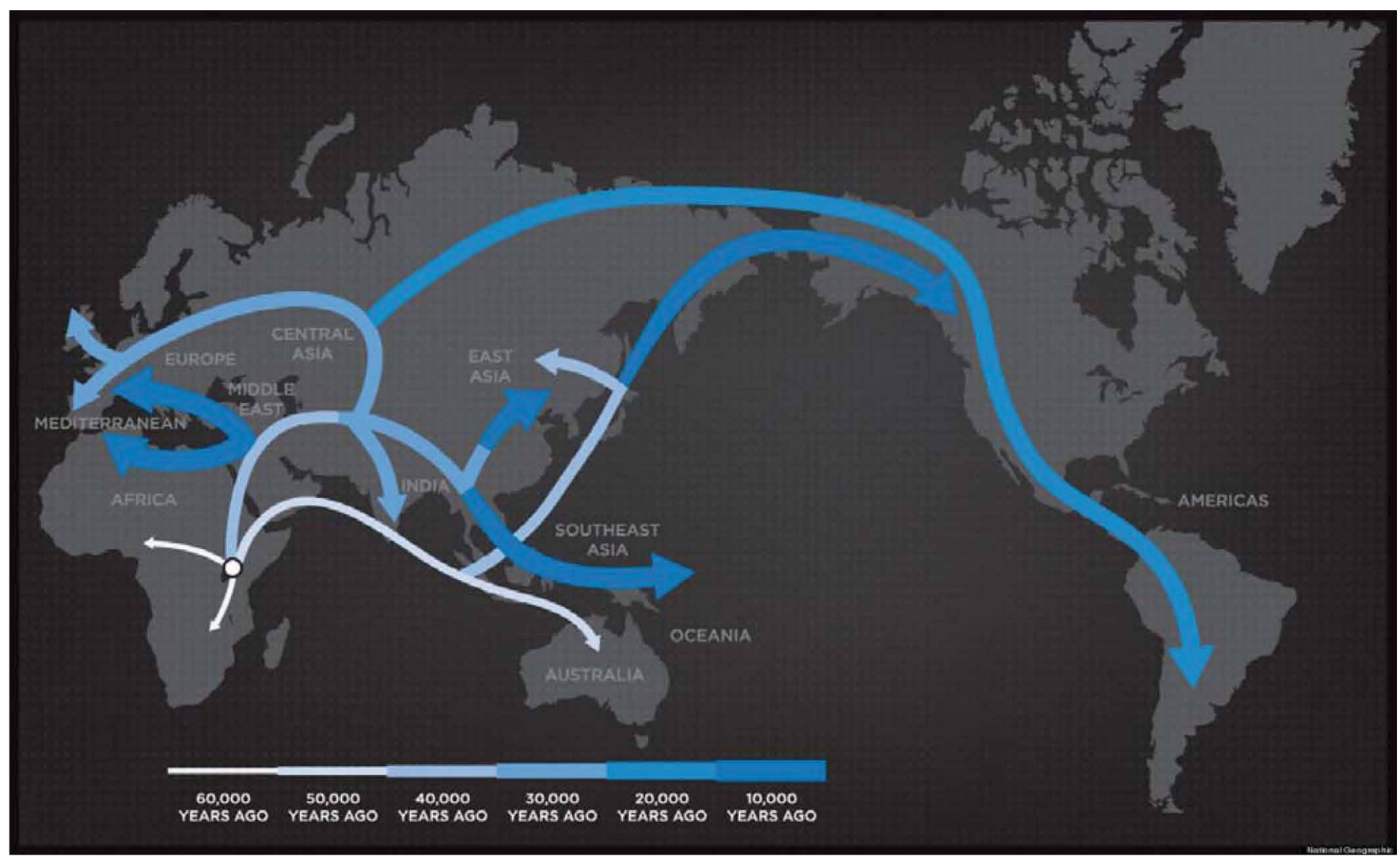

Fig. 1. Human Migration. Photo from: National Geographic/Genographic Project/ The Human Journey: Migration Routes, Fall 2014.

Within the last 50,000 years, a genetic mutation "hardwired the brain and permitted a cultural flowering seen throughout the archaeological record of the Upper Paleolithic" (Tattersall $2010,4)$.

The emergence of key areas in the brain for the production of language, such as Broca's area and Wernicke's area, are only present in modern humans. While these key structural developments allowed for the language of today, this does not mean that communication through vocalization is not utilized by other species in the primate order: "Language evolution is intimately linked to brain evolution, and since our brain has been growing and reorganizing over the past 2 million years, it seems unlikely that language suddenly arose from some radical new mutation. Human brains could have been language-competent long before spoken languages appeared" ( Johanson et al. 2006, 106). Speech, comprehension, invention, and creativity are present in non-human primates and are particularly more complex in the great apes. Studies in scientific facilities and in the wild have validated the disparity between language in humans and Animal Communication Systems (ACS). In this analysis, two major challenges emerge: one being the study of determining the universalities in vocalization, and the other is the origin of language. What allowed for this developmental shift?

There is a major difference between the ability to vocalize and the means to establish a structured system where individual units provide for an unrestricted conversation that transcends the limits of time and space. Language provides meanings to what would be unintelligible sound. When studying the origin and development of language, one must keep in mind the fact that proto-language led to the emergence of a more complex and sophisticated brain, which permitted the emergence of modern language. The development of language was a dialectical feedback process known as niche construction theory. Odling-Smee, F. J. et al. (1996) claimed that behavior shapes the genetic makeup and then that genetic makeup shapes behavior. An organism's behavior modifies the environment to suit ones survival and reproductive needs. As a result, these behaviors over time become embedded into the genetic makeup of that species. Studying primate vocalization is difficult because it is not the same as finding fossils and artifacts that can be preserved; rather, language leaves no direct empirical record. Only during the last 5,000 years have written records been documented, which accounts for roughly a very small fraction of primate history. Evolutionary linguists need to investigate what properties make humans similar to other members of the primate order, and also what circumstances provided for language development only in our species.

\section{DEFINING ANIMAL COMMUNICATION SYSTEMS}

In order to understand the origin of language studies, one has to recognize the importance of animal communication sys- 
tems (ACS). Marc Hauser, the author of Animal Communication Systems (2000), created three categories which all ACS must follow. Communication exists because it provides the species with a niche that promotes individual survival, signals that relate to mating and reproduction, and lastly calls which relate and are comprehended by members of the speech community. Why are humans the only species to possess language if it so beneficial? Evolution is a cost-effective process. Language was developed not because it was useful, but because evolution is amplified on an already existing behavior in early hominids. Behaviors performed by a singular species are acts used to increase the reproductive fitness and survival of that species: "once it was thought that things like warning calls were entirely automatic, like the way you blink if someone pokes a finger in your eye" (Bickerton 2009, 19). However, communication as stated in the categorical classification of ACS is out to benefit fitness, and this vigor means an overall survival for all kinship members in a group.

Understanding vocalization in non-human primates is a convoluted process; one must have the proper scientific perspective on communication. It is pivotal not only to comprehend primate communication, but also to obtain knowledge about all animal communication systems: "decoding the function and meaning of a foreign culture's sounds and gestures is a notoriously difficult problem" (Hauser 2000, 1). However, decoding a non-human primate call is similar to decoding a hidden message. The way to translate this message is to determine the meaning of the sounds created. Communication is ambiguous, and utterances do not describe an object directly. The only way researchers could prove the validity of what an utterance represents is by identifying the foundational background within a dynamic system, and through determining the functional meaning behind calls.

\section{DECODING VOCALIZATION}

Decoding primate vocalization is a complex task; it is more challenging than learning a foreign language, because it requires breaking a code that has no continuity and is unintelligible to its listener. The importance in differentiating the subtleties of a call from a noise is similar to humans recognizing the difference between when people cough or sneeze and speech sounds. Through habitual actions and trial and error, social species are able to differentiate calls from noise. The brain through the repetitive firing of neurons eventually creates connections that make distinctions between calls and noise. Dynamic system theory (DST) is a model that changed the science community's perspective on social communication. Animal communication, as stated, was once believed to be a detached component system. This view failed to take into account variables going beyond the individual, such as "biological (genetics), psychological (hormonal), emotional, and social factors" (King 2003, 9).

Translations from one language to another are performed by a linguist, who undergoes the process of "moving between two languages, where the meaning of words in each language is known. The difficulty as we can see is that [...] we cannot translate animal vocalizations because we lack the corresponding dictionaries (referring to a hypothetical primate dictionary)" (Hauser 2000, 2). The dynamic system is "composed of elements that are neither separate nor independent [...] as opposed to this atomistic view, dynamic systems theory argues that one can only break a system down into its constituent parts with the understanding that these elements are internally related to one another" (King 2003, 5-6). Understanding communication systems allows researchers the ability to identify the interconnected parts of the relationship between subject and object.

Humans and the great apes are living in communities with deep social roots. Environment impacts the fitness of individuals and groups directly. Gregarious primates: "Right from birth, they shape, and are shaped by, the world, through interaction with their mothers, and in many cases with other relatives and social companions as well" (King 2003, 6). The maturation period in primates is substantially longer than most species on this planet; furthermore, it takes an extensive period of time for primates to be able to survive in our environment in comparison to some species that start walking and "living" immediately after birth. Humans take such an extensive period for social growth due to the development of the brain and the necessity for relying on our communication skills, which are so vital to our survival and reproductive fitness.

Communication is constantly developing between partners. As time progresses in primate social activity, individuals in the communication system become more aware of their partners and, as a result, become more efficient in their progress for sharing information between one another. This allows for effective survival strategies and, due to this excellent communication, social behavior constitutes a pivotal role in outwitting species that are physically superior, thereby providing an example of niche construction theory in practice. As stated, determining the elements (universalities of vocalization systems) is crucial to having a proper perspective on what all communication systems share. Researchers are left with speculating on what is the foundational unit of all animal communication systems. Knowing this structure allows researchers to understand how communication systems arise in animals. Specialists in the field of communication have concluded that the basic unit in primate vocalization is a call-response: "alarm call is sufficient to elicit an escape response" (Hauser $2000,5)$. Linguists, while aware of the importance of alarm calls, are still trying to conclude if one-word commands are the foundation for structure in communication. Can these sounds be broken down or expanded to link multiple commands together to form a different alarm call? In order for anthropologists to uncover non-human vocalization, one must determine the fundamental units in the vocal repertoire. Both vervet monkeys and baboons have particular calls that allow them to defend themselves against predation. In the case of birds of prey, when a monkey makes a call, con- 
specifics in the group scan the skies for this predator. It is the same in the case of a leopard sneaking up and trying to attack a group: "We know from developmental studies that vervet infants give eagle-sounding-alarm calls to birds (creatures) that fall outside the class of predators (i.e., elephants, giraffes, lions) and that, with time, this class narrows. Consequently, it appears that vervets are born with an innate representation of something signifying 'dangerous things in the sky'. With time, experience weeds out the inappropriate items and selects for the appropriate ones" (Hauser 2000, 11). Humans are subject to the same developmental process in which, through trial and error, one develops an understanding of language. Referential theory sheds light on the belief that calls have intention and also that, like humans, non-human primates have "callspecific responses" similar to that of humans.

Breaking down this vocal code has two major roles. First, through recorded playback, one can reevaluate a call as a frame of reference. Since vocalization is not a written code, this is the only possible way of evaluating. Second, the vocal pitch and contour of the mouth make a major distinction on what call is being utilized. The reason that these two aspects are crucial to scientific inquiry is because vocal analysis is very different from the examination of written messages. These two variables allow the researcher the ability to discover the meaning behind calls.

Researchers at this time have pinpointed that "pitch contours" are crucial in the meaning behind the call. Frequency in pitch can change a call. Pitch-contours are present in human speech. Hauser has broken pitch into three important dimensions (Hauser 2000, 6):

1. Is the pitch contour a vehicle for emotional expression, comparable to the prosodic cues that we impose on our utterances? (e.g., when one is trying to emphasize a point, one cues another person through pitch.)

2. Is the contour like voice onset time for consonant-vowel pairs; something that allows us to distinguish between "ba" and "pa"?

3. Is the contour a phoneme, something that can be recombined with other sound segments, as when we create the words "super" and "pursue" by rearranging the same syllables.

Subtleties in pitch permit researchers to identify particular calls that pertain to specific social contexts. The differentiation among calls of rhesus monkeys and baboons have proven that pitch is a key universal indicator. Monkeys were subjected to tests in which they heard play-back calls from hidden speakers. The experiments categorized the calls into "grunts" (used as a pleasantry), barks as a form of threat, and copulation screams in terms of satisfaction (Hauser 2000, 8; Cheney et al. 2008, 80-83). Cheney's studies were in the context of social hierarchy. In baboon communities, this evidence demonstrated the usage of internal structural changes in pitch and their usage for particular situations. The next step in the scientific investigation was to determine: "how subjects would respond to a signal that combined a pulse from a grunt with one from a copulation scream" (Hauser 2000, 7). In the early stages of vocalization studies, primates were considered to naturally have a set of vocal signals in which each call, or occasionally a combination of calls, meant something particular. Research performed on non-human primates has led specialists to the hypothesis that primates use their vocalizations as a form of expressing their emotions. This behavior is comparable to human infancy, in which children cry when hungry, angry, or in pain. This premise on the emergence of human vocalization is an extension of an already superimposed system. Hauser stated that this has been the common consensus, but utilizing communication for expression of emotions is not the only reason animals communicate; some animal sounds are referential, which means: "That a listener could derive relevant information about the context," which triggers in the mind a particular event or object. However, in order to study this discipline, Hauser claimed that we need to have four criteria in mind (Hauser 2000, 10):

1. Calls represent the lowest level in terms of functional units.

2. Particular social situations result in specific arbitrary calls at that moment, not past or future situations.

3. Primate calls represent whole objects, not particularities of the object (assuming primates are compared to children in their early stages of development).

4. Assumption that the animal is calling with the intention to warn others.

These principles are crucial in maintaining a focus on discovering a "primate dictionary." What allows cryptanalysts the ability to determine a message with efficiency is finding repetitions in a decoded message. However, in some cases, as in the usage of a homophonic substitution, "each letter is replaced with a variety of substitutes" (Singh 2000, 52). In rhesus monkeys there is this practice, where calls identify food sources. This type of communication is dependent on the type of food discovered. Hauser's results identify a context that one can understand:

Consider, as an analogy to the rhesus case, a translation of warble into 'caviar', harmonic arch into 'fish eggs' and grunt into 'potato.' Now imagine that you hear someone at a restaurant repeatedly saying 'potato' as he eats forkful after forkful. Eventually, you habituate and carry on eating your own meal. If, all of a sudden, your vocal neighbor says 'caviar', you would presumably perk up and orient, not because of an acoustic difference but because of a referential difference, and a meaningful one at that. Conversely, if he starts repeating 'caviar' and then switches to 'fish eggs' an acoustic difference would certainly be noticed, but there is only a trivially important referential difference (Hauser 2000, 12). 
The subtle difference between a warble and a harmonic arch distinguishes between differing terms for a type food. Grunts, in this example, are significant because there is no conceptual relation to the other terms. However, in all cases, the ability to recognize differing terms is present. This data shows that primate vocalization is more complex than just simply an expression of emotion; it is used as a way to convey information about objects and events. What allows researchers the ability to make this inference is dependent upon the call having specific identity. This is proven based on the reactions that conspecifics have in the context of a call.

ACS are founded on functional reference in which species pick out an object in the environment and direct the attention of group members toward it. The main importance of these calls is to provoke a particular response from the listener. In the case of vervet calls, they are not specifically directed toward a referent in the world. In ACS, there is no necessity for particularities in vocalization. As long as the call serves the purpose of survival, then there is no need for a specialization of the communication system. Objects are only utilized for explicit events revolving around survival and reproduction. Vervet calls are "specific responses to specific situations, complete in themselves, and more than that, they're responses that have had, in the past, a demonstrated capacity to improve the fitness of those that used them" (Bickerton 2009, 45). If the calls did not result in longer lives and more offspring for individuals, then they would have never been passed on as learned behavior. From a niche construction framework, contextual calls make sense in vervet monkeys: "Vervets needed alarm calls because they were heavily predated," and over time these calls were eventually ingrained in their (instinctual) evolutionary makeup (Bickerton 2009, 116; Burling 2005, 51-52).

Non-human vocalization appears limited in its complexity, but for those species that possess these qualities, they know of no supplementary method. Their means of communication allows them to enhance their fitness through manipulation. Humans use language primarily for informative means. The fundamental difference between these two systems is that "ACS units are indexical because they're designed to manipulate others. Those others have to be right there in the present time at the present place if they're going to be manipulated" (Bickerton 2009, 48). Language, on the other hand, is symbolically designed to share information past, present, and future: "we mentally decompose the world around us into a vocabulary of discrete symbols, which we can combine and recombine in our minds to imagine alternative worlds" (Tattersall 2010, 2). The capacity to transcend time and space is known as displacement. Displacement is crucial for the existence of language. If symbolic communication did not allow individuals the ability to signal or warn others, then the ability to discuss future events and reminisce on past proceedings would never have persisted in humans.

\section{THE HOMINID-PONGID SPLIT AND ITS IMPACT ON LANGUAGE}

Research has been conducted on primate vocalization for the past century, and was inspired by the discovery of the alarmingly similar genetic makeup that we share with the pongids. As a result, "more and more people assumed that most if not all of what had been seen as typically human traits and behaviors were no more than expansions of traits and behaviors found among the apes" (Bickerton 2009, 55). Extensive research has been done by scientists to test this theory. It was held that if one is going to find precursors to language, then the antecedents would be present in these species. Evidence has shown that each species follows its own adaptive niche, it is not a linear progression. The difficulty that science has been left with is that language and symbolic studies are trying to get into the minds of these apes. Does one know if these pongids are aware of what they are doing? In experiments, the great apes may have the ability to perform certain tasks, but will they understand the reasoning behind their actions? Are pongids merely mirroring scientists, or are the great apes able to create meanings behind these abstract and critical concepts? The difference between symbolic and non-symbolic communication is that the former system refers to symbols without the objects physically being present.

To understand why the pongids are so similar to humans, one must focus on the individual characteristics that make the great apes unique, while keeping in mind that communication systems are designed solely to take care of a species' own evolutionary needs. There's no evidence of a universal cumulative or progressive trend in communication systems. However, humans unintentionally follow a human-centric bias that places our species in a hierarchy above other species.

In non-human primates, communication is not as sophisticated as human language. In many cases, it is just a form of warning other primates there is danger approaching. Chimpanzees vocalize with as many as 34 distinct calls; their rough grunting is a form of greeting to members of higher status. Vocalization for chimpanzee, through the forms of grunts, is also a form of excitement toward food, which is shown in mother and infant bonding. While this vocalization demonstrates intelligence in chimpanzees, it is also present in the other three pongids (bonobo, gorilla, and orangutan). In many cases, this communication is not enough evidence to prove that these species have meanings behind their calls. Scientists claim that cognitive ability is not utilized, because the environment does not demand them to alter their ways of living. This statement has been the major debate over what is the true influence in obtaining proto-human cognitive traits: "Without biology (life), behavior cannot occur and [a] physical attribute cannot be manifest. Without experiences in diverse environments, the organism cannot achieve development, maturation, conditioning, and other kinds of learning" (Rumbaugh et al. 2003, 42). The notion that nature and nurture play hand-in-hand took decades for researchers to under- 


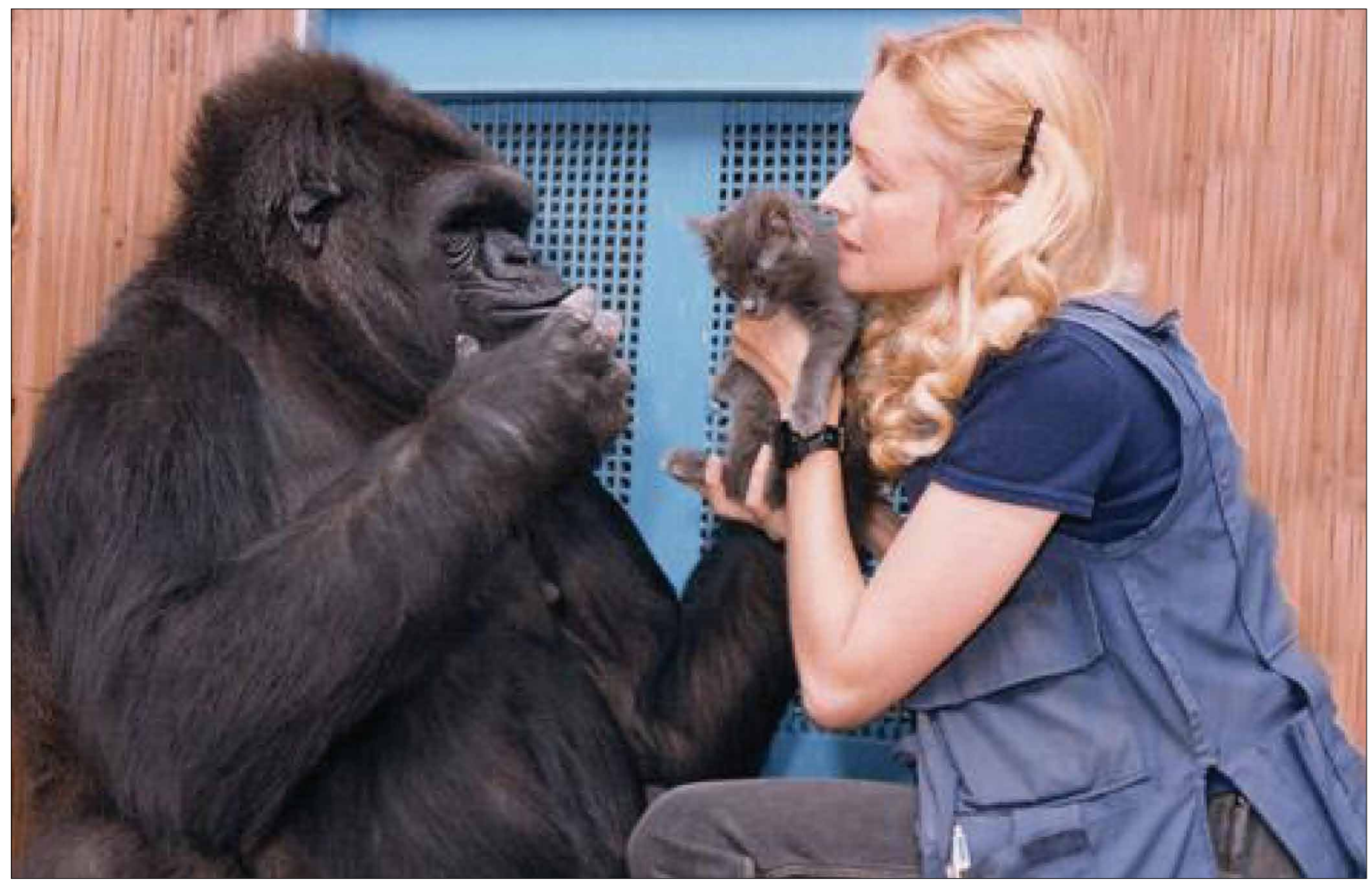

Fig. 2. Koko the Western Lowland Gorilla Performing Sign Language Photo from: flyladylori.com/2011/07/happy-40th-birthday-koko-the-talking-gorilla/, April, 2011.

stand. As a result of an inaccurate analysis of the complexity of animals, researchers were running ineffective experiments on the non-human primates. What scientists must keep in mind is that human communication is not an ideal form of exchanging information. The misconception that individuals fail to understand the process of evolution is that adaptation follows a path that is species specific.

Naturally, humans subjectively judge foreign communication systems. Humans are subject to this attitude because as a social species our species is dependent on processing information through language. It is unimaginable to rationalize a world without symbolic language through articulate speech. Non-human primates, while not being able to use language, are able to communicate in a manner that is acceptable for their evolutionary niche. They have constructed communication behavior that has allowed them to successfully survive and reproduce.

The capabilities of a species, such as the chimpanzee, must be accounted for not only in their biological and anatomical makeup, but also in their behavior. The anatomy of our closest living genetic relative, the chimpanzee, has been of major consideration, specifically in the behavioral characteristics needed to allow for human language. Evidence has shown that the vocal folds in a chimpanzee's throat are too fatty and less muscular than those of humans. Another contrasting difference is that the neurological pathways between the brain and the vocal folds are less sophisticated in chimpanzees than they are in humans. Structurally, the larynx area is what allows humans to articulate effectively; in chimpanzees, the epiglottis extends much higher in the throat, lessening the range of sounds it can produce. As a result, this biological makeup proves that apes are unable to achieve oral language production. This evidence has caused scientists to rethink the study of chimps and other pongids. The science community is divided on which method of symbolic studies is most effective in studying primates: American Sign Language (ASL) and lexigram approaches are two popular methods of testing and communicating with pongids. The first ASL study, from 1965 to 1972, was established by Allen and Beatrice Gardener, who reared a chimpanzee as they would a child. Washoe the chimp was able to utilize language in a creative manner. In three years, Washoe was able to learn 130 signs, and her behavior shed light on the capabilities of the chimp brain. While there is still skepticism about this experiment, because of the cues that the chimp could have been given, multiple studies have been performed to test the validity of these results. Scientists altered the methods used by creating a double-blind test. A double-blind study uses multiple experimenters to prevent the altering of data. 


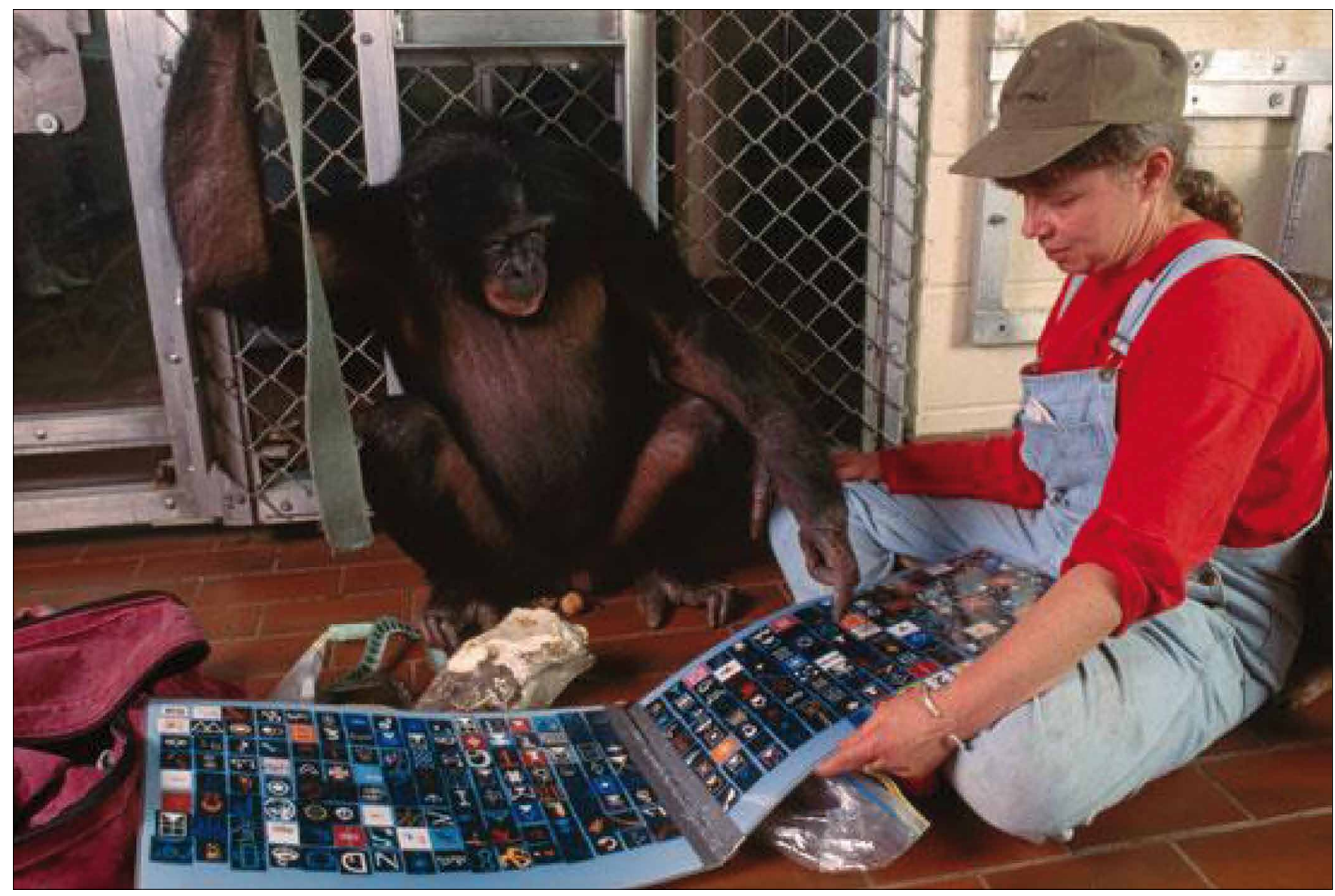

Fig. 3. Sue Savage-Rumbaugh with Panbanisha---Anna Clopet/Corbis. Photo from: advocacy.britannica.com/blog/advocacy/2007/11/the-language-of apes/\#sthash.fl4tqTSK.dpuf, November, 2007.

Researchers, such as Roger Fouts, argue that humans are not the only species to have social and cognitive behaviors. Since the 1960s, science has tested the limits of intelligence in chimpanzees and other non-human primates. Fouts holds that language needs to be redefined in a broader scope, because other species use forms of vocal communication differently. In the most current research studies of our closest living evolutionary cousins, researchers have altered the environment in which these pongids live. Consequently, these experiments have tested the creativity and malleability of the brain in the context of problem solving. In 1999, the University of Georgia used a method of entrenching the pongids in a human-like atmosphere. Panzee, a chimpanzee (Pan troglodytes), and Panbanisha, a bonobo (Pan paniscus), were raised from six weeks of age and lived within a human society. The study's purpose "was to examine the apes' spontaneous, untutored mastery of the word-lexigrams and to see whether Panzee would come to comprehend human speech" (Rumbaugh et al. 2003, 4).

Lexigrams are visual symbols that are keys on a keyboard that light up when pressed by the ape. This research tested the complexity and intelligence of Panzee and her ability to use multiple senses to achieve the task at hand. With the acquired skills that Panzee learned throughout her life, she was given an opportunity to solve problems ingeniously. In a multiple trial experiment, researchers would take an item, in many cases a fruit, and place it in a brush area a few yards away from Panzee's fenced-in habitat. In order to make this study void of human error, a double-blind experiment was used. One scientist would place the item in a location while another scientist would help Panzee retrieve the item, which was outside of her reach. Panzee achieved success by using multiple forms of communication. First, she displayed her hindquarters as a form of greeting. Next, she went to a keyboard and pointed to the picture of the kiwifruit. Then, she went through a tunnel to the outside cage where she helped direct the scientist to the location of the fruit. One may find this behavior hard to imagine, but the test was replicated many times with a wide variety of items. The normal time frame in which Panzee would inform someone of the object was usually within a twenty-four hour span, but there were cases where she waited days or even weeks.

The mastery of word lexigrams was paramount in Panzee's development of human language comprehension. Otherwise, it would have been impossible for her to identify the food hidden and the materials that hide it. The compilation of gestures, pointing, and the acquisition of vocabulary demonstrated the 
highly complex brain functions that pongids possess (Rumbaugh et al. 2003, 6). People are simply misinformed when they assert that our species has distinct physical features and cognitive qualities that separates us from the other animals on this planet. The differences in humans from the apes may seem significant, but in the grand scheme of evolution, they are miniscule. These adaptive differences are the result of genetic mutability on the species level. Such genetic changes are a result of humans being altered by the conditions of their environment over millions of years.

Non-human primates, while not having the same biological complexity as our own species, still show evidence that they are capable of vocal communication, complex learning, and invention. How can the science community achieve success in understanding these non-human primates? It comes down to the ability of humans to "talk" to the chimpanzee and other primates. How is it possible to speak to an ape? Briefly, it requires understanding and comprehending primate body language. Rumbaugh proved that chimpanzees do not have the verbal communication skills necessary to understand their own private experiences. Consequentially, Rumbaugh illustrated that non-verbal evidence is as valid and, in most cases, more reliable than merely personal observations (Rumbaugh et al. 2003, 56).

\begin{abstract}
As I prepared to start the engine, I noted the distinctive pattern of fresh chimpanzee teeth embossed in what had been the flawless, beautiful black padded cushion atop the dash. With dismay, even disgust, I complained, 'How did these get here?' The reply from Sue was, 'Panzee did it as she came across your seat. You have to watch her!' My penetrating eyes then focused upon Panzee's as I pointed to the teeth marks and asked her in earnest, 'Panzee! Did you do this? I'm really disappointed in you.' I really didn't expect to be 'heard', she then took my right hand, opened and held it, palm up, in her left hand. She then brought her closed right hand across her body, opened it, and gently pressed something-which I did not know that she had-- into my hand. She never broke her focused attention to my eyes as she did so. Next, she firmly closed my fingers about the item and pressed my closed hand to my chest... Only then did I open my hand and find the item she pressed into my hand, a single flower.
\end{abstract}

Rumbaugh's experiences were unique and cannot be explained merely in terms of his interpretation of the situation. It is analogous to a parent speaking to a young child who is unable to articulate his or her feelings. This single event has motivated scientists to come up with an explanation for this social phenomenon. The ability of the brain to instinctively respond and operate is referred to as rational behaviorism. Thus, rational behaviorism includes learning, memory, and selective recollection that are the focus of an advanced organism. Without these complex specializations, animals are unable to effectively remember past experiences, which could lead to their demise in an ever-changing environment. Behavior is a reaction to stimuli both in the past and present. Without being able to adapt to the dynamic world around them, there would be no living organisms present on the earth.

Traditional behaviorism, grounded in the Cartesian philosophy, advocated that animals were merely walking biological machines. However, this fails to take into account the social and decision making processes of organism. Even Darwin held that all organisms are the result of the survival of the fittest, based on the biological makeup of creatures. Besides the shift to acknowledging the influence of genetic makeup, the psychological function of "mental operations" is also vital to the survival of not only an organism, but also the species. While all species are diverse, this does not mean that humans are not similar to other animals. All present life forms have evolved from one common organic source billions of years ago. The main point is that all organisms are similar in that they experience the natural world around them. If humans are unable to creatively adjust to environmental changes, then they will become extinct. As a consequence of this comparative research, scientists have a particular interest in studying the great apes: "thus, notably in the great apes and human children, the brain is competent to organize predictions that are valid both within contexts and between contexts [...] Thinking, reasoning, insight, organization, and prediction somehow benefit from coordinated efforts to adapt" (Rumbaugh et al. 2003, 286). Humans are not the only species to have the potential for psychological intelligence through vocal communication. All primates share an underlying similarity; they have a natural inclination to control their environment in order to survive and reproduce.

In the event of teaching non-human primates sign language or the ability to comprehend and utilize lexigrams, experiments demonstrate the already-known claim that pongids and other non-human primates are subject to following an ego-centered ACS perspective. Even in the case of Kanzi: "the Einstein of apes, [all that any ape] ever talks about are things like where they want to go, what they want (or want you) to do, or what they'd like to eat" (Bickerton 2009, 78). Reflective, past-oriented, and future-oriented information is non-existent in non-human primates; animal communication systems are primarily manipulative in motivation. In no cases have scientists found behaviors remotely similar to proto-language. What allows for apes to comprehend and spontaneously put signs together is held to be that "the presentation of novel signs [by humans] to apes, coupled with the presentation of physical objects, caused certain neurons to fire simultaneously [in the apes] that had never fired simultaneously before" (Bickerton 2009 82). With the repeated exposures to these signs, the pongids were able to associate signs with meanings. However, if it were not for the intervention of the human species, then this association would never have happened because the apes' natural environments do not cause such stimulation. 


\section{THE EMERGENCE OF LANGUAGE FROM PRIMATE COMMUNICATION}

In order for language to emerge out of an animal communication system, there would have to be an already "existing behavior that could be taken and twisted and refined into an appropriated medium," and then this behavior is directly used to benefit fitness (Bickerton 2009, 21). There has to be a shift from contextual situations to the formation of individual meaningful units. It is all based on a cognitive process. Nonhuman species use categorical sorting, while humans have concepts: "Categories sort things into classes but can only be evoked by physical evidence that members of those classes are present. Concepts sort things into classes but can in addition be evoked by other concepts even in the absence of members of any of the classes concerned" (Bickerton 2009, 210). The isolation of individual objects in the world, not only in the present time, but also by abstractly discussing objects from the past, present, and future occasions, provides a cross-over from animal communication systems to human symbolic language. Non-human primates are only able to vocalize situations that occur in the present, not in past or future: "Each utterance of an ACS unit is tied to whatever is going on in the immediate vicinity right at the moment. Words, on the contrary, are relatively seldom used about what's going on before our eyes" (Bickerton 2009, 22). The beautiful thing about language is that one can exchange an infinite amount of ideas without having any constraints in time and space. Furthermore, while language is beneficial to Homo sapiens sapiens, this does not entail that language is a part of a progressive development that all species will eventually achieve. The only reason that humans formulated language was because "social interaction must have been the pressure that selected for language" (Bickerton 2009, 26). What were the conditions that allowed for language to surface in humans? It was a result of uniqueness, environment, credibility, and selfishness.

Uniqueness because language is only present in humans. If this form of communication were present in other species, then scientists, through comparative methods, would pinpoint its distinct feature. Science is left with the challenging task of interpreting what allowed for language to develop so successfully in humans, since research has no trace of language in other organisms. Proto-language had to form in a logical manner based on the contextual setting of a changing ecological environment. It had to have emerged in an environment during the Pliocene in central East Africa: "Our remote ancestors may not have been much smarter than their ape cousins, but they lived in dramatically different environments and made their living in completely different ways" (Bickerton 2009, 30).

Credibility entails that the emergence of linguistic units and their accepted meanings follow an adaptive, continued existence, and reproductive sequence; without these three factors, language would have never developed. The last condition that had to be fulfilled was that the emergence of language had to account for selfishness. Subsequently, a theory of language

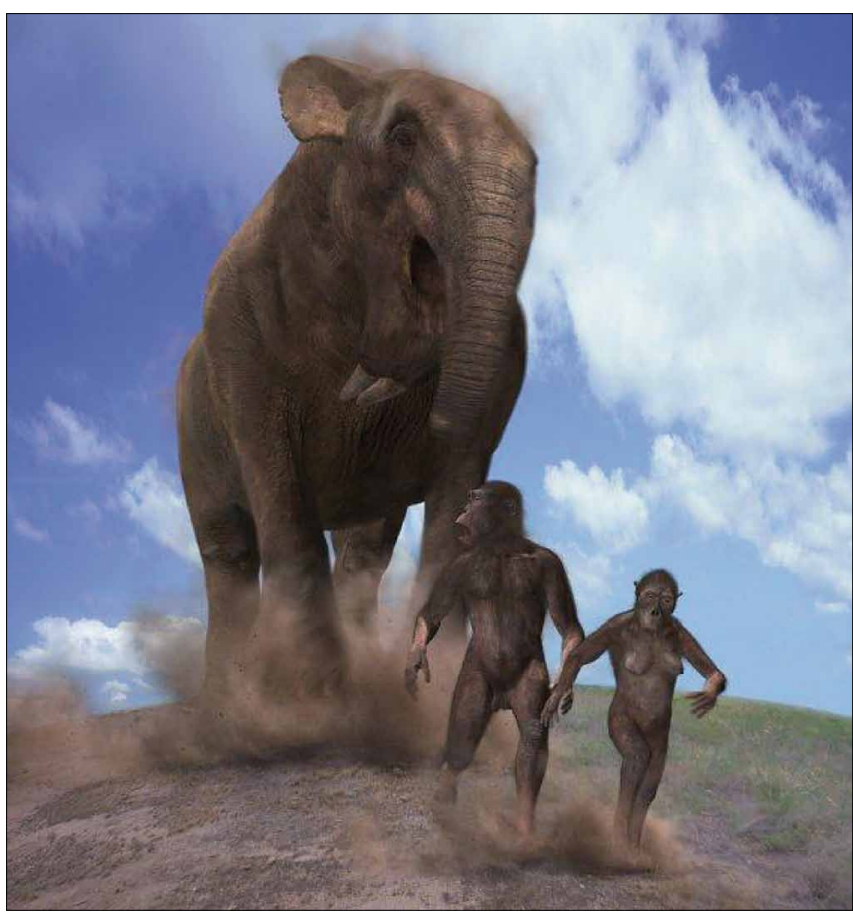

Fig. 4. Australopithecus africanus running From an Angry Deinotherium. Photo from: walkingwithdinos.wikia.com/wiki/File:038.jpg, April, 2011.

can either be interpreted from Richard Dawkins' perspective, in which selfish genes allowed for the advancement of an organism's offspring, or from the belief in David Bickerton's "group selection." The latter theory takes into account that individuals sacrifice for the betterment of a group, in which "the speaker derived (at least!) as much benefit from them as the hearer did" (Bickerton 2009, 32). However, both thinkers contribute to the speculation on the origin of language. But what allowed for a proto-language to form in early hominids? In the case of our early ancestors, one has to put into perspective three primary guidelines: the habitat, nourishment, and the means of obtaining food. Early hominids lived in open woodlands and on grassy savannahs; this environment is comparable with the landscape that the baboons of today inhabit. Australopithecines were "neither a bold hunter nor a vicious cannibal, but a weak and furtive scavenger, nervously looking over its shoulder in fear" (Smith 2009, 23). Predation led australopithecines to be subjected to living off the bottom of the scavenging food chain. Bone marrow provided for sustenance and nutrition. The issue is that the fat and caloric value in a bone was not of large quantity, so it took lots of bones to satisfy hunger. Creativity was fundamental in the development of language; australopithecines used primitive tools such as flint in order to cut through the thick leathery hides of megafauna. In order to survive on the savannah, these large animals capitalized on their size for the ongoing survival of their species: "The size niche exists, permanently, within an order, simply because if you're bigger than anything else around, you're virtually invulnerable to attack" (Bickerton 2009,122$)$. Hominids were able to take the opportunity to 


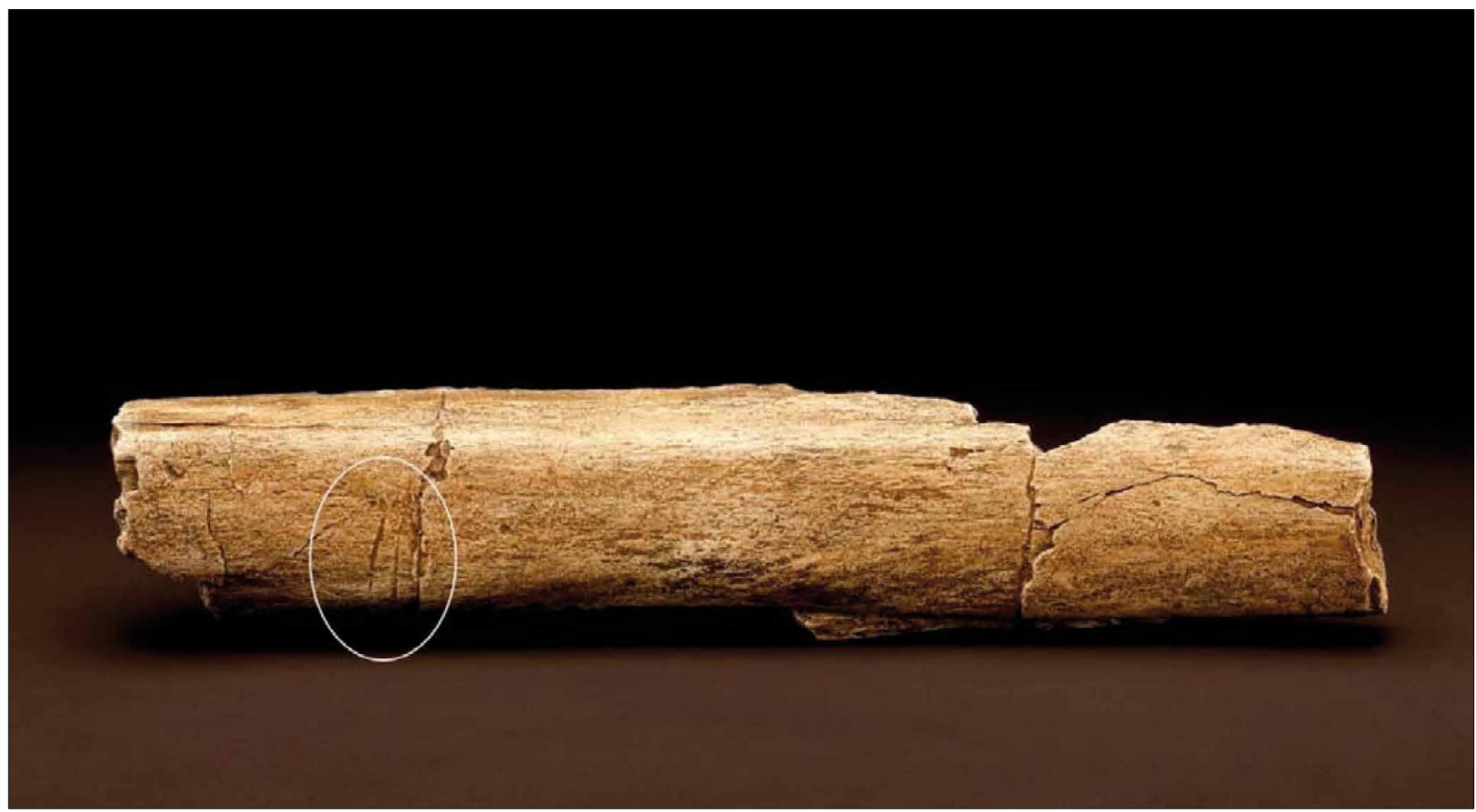

Fig. 5. Elephas Recki Fossil Rib with Cut Marks. Image Courtesy of Chip Clark, Smithsonian Institution. Photo from: humanorigins.si.edu/research/east-african-research/olorgesailie, October, 2014.

utilize hand weapons, which gave them a competitive advantage to access carcasses of large megafauna, whose skin was impenetrable to predators' teeth.

Prior to australopithecines using tools, scavengers waited for bacteria to break down the animals hide; gases from inside expanded to rupture holes in this thick skin. How do we know this is plausible? Dominguez-Rodrigo claimed that if hominids were denied access to these large mammal carcasses, then the "midshafts of upper and intermediate limb bones would already be defleshed when accessed by hominids" (Dominquez-Rodrigo 2005, 118). Through the forensic investigation of early hominid sites, in contact with megafauna, researchers have found that, due to indentation marks left on bone, there was a shift in this period in which cut marks impacted bone before non-hominid teeth marks. This evidence demonstrates that the australopithecines were arriving at scavenging sites and retrieving meat before other predators arrived.

Optimal foraging theory, under these conditions, allows for emergence of a proto-language. Without collective effort to fend off predators, while members of a group hacked off pieces of meat from a carcass, it would be impossible: "exchanging information about the scavenging of megafauna is one case that overcame this problem. If I don't tell others about the dead deinotherium, there's no benefit. I can't exploit it for myself alone" (Bickerton 2009, 168).

In order to rally other members of a group together, one must entice them with the belief that they would be able to receive compensation for their efforts. What allowed com- munication to expand from simply iconic representations of animal's sounds was hominid creativity and ingenuity. This cultural stimulus tapped into an untapped potential never expressed before. These factors were needed in order for an early form of proto-language and later language to break away from an animal communication system, thereby expanding communication into an informative, symbolic, and displaced system.

The evolutionary development of the brain was due to a selective process. In the early stages of emergence, hominids feared larger prey. Selective scavenging allowed for a constructive niche, which allowed for genetic development in the realm of the reconfiguration and complexity of the brain. As a result, hominids were able to outsmart the predators that they feared. Through coalitionary aggression, hominids banded together in highly organized ways, using proto-language to augment their limitations in size; they also improved on their exploits through memories of past conquests and plans for future success.

For a niche to be actively constructed, a species must develop an adaptive behavior toward their environment, and in turn the niche helps to evolve the species: "conventionalizations of even the earliest words were never passed down by the genes. Rather, they had to be learned anew by the members of each generation" (Bickerton 2009, 219). This incorporates the major importance of comprehension (Burling 2005, 21). For a species to be able to specialize in communication, it has to be able to understand the meaning behind arbitrary signs. 


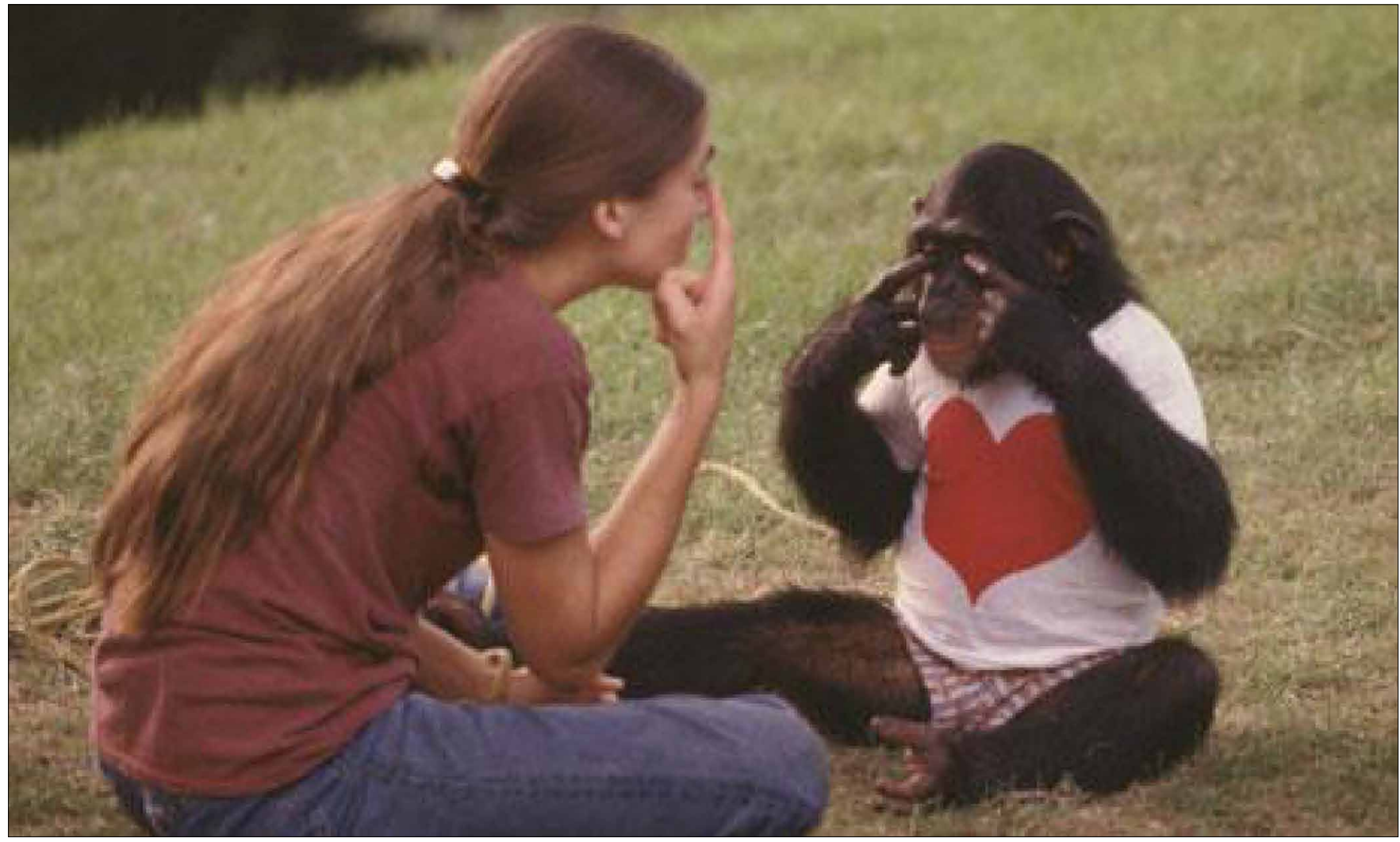

Fig. 6. Nim Chimpski Signing. Photo from: theguardian.com/film/movie/142243/project-nim.

\section{FINAL REMARKS}

Niche construction theory is the proper framework for examining language origins. Science has already proven that humans share a significantly similar genetic makeup with the great apes. So there must be a niche or multiple niches that one may construct in which early hominids evolved after their separation from fossil great apes. Bickerton stated that humans have "at least six distinct niches: a terrestrial omnivore niche, a low-end scavenging niche, a high-end scavenging niche, a hunting and gathering niche, a herding niche and an agricultural niche" (Bickerton 2009, 109). Through experience, this would not be possible if genetic determinism were in place, because then everything would be predetermined in nature: "When environments change, some members of a species often survive, and they can do this only by doing things that their genetic equipment allows, but that they had never done before, because they'd never had to do such things" (Bickerton 2009, 84). In order to survive, a species has to have ingenuity in using unorthodox methods, but in the confines of their potentiality. The ability for hominids to develop a proto-language is due to selective pressures that allowed for this specific behavioral development. A large misconception people have about genetics is the thought that genes mandate behaviors, but this is false. Genes simply make behaviors possible: "Circumstances will determine how far, if at all, those possibilities are realize[d]" (Bickerton 2009, 115). In addition, it is important to emphasis that both Dawkins theory about the selfish gene and Bickerton's theory of group selection are both significant in understanding evolution. It is the interplay and dialectical relationship between the evolutionary desires for individual survival versus collectivism which allowed for the emergence of modern humans with symbolic language as articulate speech.

Determining the capabilities of early hominids is vital to understanding the similarities humans share with other organisms. Cross-collaborative efforts to answer the mysteries of our species are necessary. Most recently, interdisciplinary efforts in the field of biological and linguistic anthropology have led to the discovery of ossicle bones in early hominid species: both Australopithecus afarensis and Homo habilis in cave sites at Swartkrans and Sterkfontein. This discovery is significant, because these small bones aid in the transmission of sounds and allow for more accurate hearing. As a result, researchers have more evidence to promote the hypothesis that language was able to develop in these species because of this anatomical development. Furthermore, primatologists have historically challenge ideas about the capabilities of non-human primates. Sometimes to a point where the ethical boundaries of experimentation are pushed. In particular, Project Nim (1973-2010) showed that Nim Chimpski, a chimpanzee, was raised as a child and was taught sign language over a course of years. However, over the course of his development, researchers from Columbia University determined that Nim could 
not grasp the rules of grammar. While this investigation was groundbreaking, it has also been criticized by contemporaries for its unorthodox methods and inhumane treatment of its subject. Nim was a wild animal and the researchers failed to take this into account when their subject became impossible to manage after he became a full grown adult male chimpanzee. At present, this experiment is the only spontaneous animal sign language test openly available to the public.

Most recently, Charles Yang, a professor of linguistics at the University of Pennsylvania, applied predictive models to determine if a two-year-old child was able to distinguish rules of grammar or simply imitate their parents. Yang tested the competence of two-year-old children and Nim's ability to properly use indirect and direct articles. Charles Yang's research concluded that true language learning is a uniquely human trait, and that it is present very early in development. These examples are current endeavors in the field of linguistic anthropology and with more empirical evidence, anthropologists will solve those issues that still perplex the understanding of and appreciation for the evolution of language.

\section{ACKNOWLEDGEMENTS}

The preparation of this article was dedicated to my distinguished professor Dr. H. James Birx. His guidance, support, and insight throughout my academic and professional career has been pivotal to my development as an applied anthropologist.

\section{REFERENCES}

Bickerton, D. (2009): Adam's Tongue. New York, Hill and Wang.

Birx, H. J. (2010): Evolution: As I See It. In: Anthropologia Integra. Czech Republic, Masaryk University Press. 1 (2):7-10.

Birx, H. J. (1988): Human Evolution. Spring Field, Charles C Thomas.

Burling, R. (2005): The Talking Ape: How Language Evolved. New York, Oxford Press.

Cheney, L. D. with Seyfarth, M. R. (2008): Baboon Metaphysics: The Evolution of a Social Mind. Chicago, University of Chicago.

Chomsky, N. (2000): New Horizons in the Study of Language and Mind. Cambridge, Cambridge University Press.

Chrosniak, P. N. (2010): Linguistics. In H. J. Birx (Ed.), $21^{\text {st }}$ Century Anthropology: A Reference Handbook (Vol. 1, Chapter 26). Pp.258-268. Thousand Oaks, Sage.

Darwin, C. (1998): The Decent of Man. New York, Prometheus Books. (originally published in 1871)

de Waal, F. (2013): The Bonobo and The Atheist: In Search of Humanism Among The Primates. New York, W. W. Norton \& Company.

de Waal, F. (1996): Good Natured: The Origins of Right and Wrong in Humans and Other Animals. Cambridge, Harvard University Press.

Deacon, T. (1997): The Symbolic Species: The Co-evolution of Language and the Brain. New York: W. W. Norton \& Company.

Dominguez-Rodrigo. (2005): Cutmarked Bones From Pliocene Archaeological Sites at Gona, Afar, Ethiopia: Implications for the Function of the World's Oldest Stone Tools. In: Journal of Human Evolution. 48: 109-121.

Duranti, A. (2001): Linguistic Anthropology. In: International Encyclopedia of The Social \& Behavioral Sciences. Oxford, Elsevier Science Ltd. 1 (1):8899-906.

Fouts, Roger S. with Fouts, Deborah H. (1999): Chimpanzee Sign Language Research. In: Phyllis Dolhinow and Agustin Fuentes, (Eds), Pp. 252-56.
The Nonhuman Primates. Mountain View, California, Mayfield Publishing Company.

Hauser, D. M. (2000): A Primate Dictionary: Decoding the function and meaning of another species. In: Sciencedirect. 24 (3):445-75.

Hockett, C. D. (1960): The Origin of Speech. In: Scientific America. 203(3):8889.

O'Grady, W. with Archibald, J. (2004): Contemporary Linguistics. New York, Bedford/ St. Martin.

Odling-Smee, F. J. et al. (1996): Niche construction. In: American Naturalist 147 (1): 641-48.

Johanson, D. with Edgar, B. (2006): From Lucy to Language. New York, Simon \& Schuster.

King, J. B. (2003): How Can We Know the Dancer From The Dance? In: Sage, Anthropological Theory 3(1): 5-26.

Pinker, S. (1995): The Language Instinct: How the Mind Creates Language. New York, Perennial.

Rhoades, J. D. (2010): Communication and Symbolism. In H. J. Birx (Ed.), $21^{\text {st }}$ Century Anthropology: A Reference Handbook (Vol. 1, Chapter 27). Pp.269-76. Thousand Oaks, Sage.

Rumbaugh, M. D. with Washburn. A. D. (2003): Intelligence of Apes and Other Rational Beings. New Haven, Yale University Press.

Singh, S. (2000): The Code Book: The Science of Secrecy from Ancient Egypt to Quantum Cryptography. New York, Anchor Books.

Smith, L. D. (2009): The Most Dangerous Animal: Human Nature and the Origins of War. New York, St. Martin's Griffin.

Tattersall, I. (2010): The Rise of Modern Humans. In Evolution: Education and Outreach. Springer New York Online. 1 (1): 1936-6434.

Terrace, H. S. (1987): Nim, A Chimpanzee who Learned Sign Language. New York, Columbia University Press.

Trubits, R. J. (2011): Chimpanzees, Bonobos, \& Humans: A Contrast in Behavior \& Evolutionary Significance. In: Anthropologia Integra. Czech Republic. Masaryk University Press, 2(1): 7-17.

Trubits, R. J. (2010): Primate Research Studies. In H. J. Birx (Ed.), $21^{\text {st }}$ Century Anthropology: A Reference Handbook (Vol. 2, Chapter 63, pp. 633-646). Thousand Oaks, Sage.

Trubits, R. J. (2009): The Hominid-Pongid Split. In H. J. Birx (Ed.), Encyclopedia of Time (Vol. 2, pp.675-677). Thousand Oaks, Sage.

Whorf, B. L. (1956): Language, Thought, and Reality, Selected Writings. Cambridge, MIT Press.

Yang, C. (2013): Penn Research Shows that Young Children have Grammar and Chimpanzees Don't. In: Penn News. Philadelphia, University of Pennsylvania.

\section{AUTHOR}

Ryan J. Trubits received a B.S. degree cum laude from Canisius College in Buffalo, New York, majoring in both anthropology and history, with a minor in philosophy. The recipient of the national Eugene Buechel Award for excellence in anthropological achievements, he focused his research as an undergraduate student on hominid-pongid evolution, the emergence of language, and primate behavior which led to him authoring seven publications for academic journals and encyclopedias. As an AmeriCorps VISTA (Volunteers in Service to America) member, Ryan utilized his research and editing skills from undergraduate studies toward grant writing for the NativityMiguel Middle School of Buffalo. His talents resulted in a successful year of sustainable growth and profitable service bringing in $\$ 52,820$ total cash resources and $\$ 8,987$ in non-cash resources. In November 2011, Ryan was accepted into the Peace Corps where he was a public health volunteer. During his service in Guinea, he offered preventative health education to the citizens of Koliagbe. Ryan focused on bringing about positive behavior change through the recruitment, training, and performing of sensitizations with high school and university students at the grassroots level. After the completion of his national and international service, Ryan returned to higher education in order to complete his Master's degree in applied anthropology and to further develop his skills in community outreach. Email: RyanTrubits@my.unt.edu 